\title{
Library Skills, Critical Thinking, and the Teacher-training Curriculum
}

\section{Nancyanne O'Hanlon}

Elementary schoolteachers play an important part in the development of both bibliographic skills and the critical-thinking skills that are necessary to complete research tasks successfully. This paper describes the results of a survey of elementary-education faculty at teacher-training institutions in Ohio designed to explore attitudes toward the elementary schoolteacher's role in research skills instruction and toward library instruction in teacher-training programs. Results indicated strong support for teaching of library skills to future teachers, but also some ambiguity concerning the relationship of critical-thinking skills to the library research process.

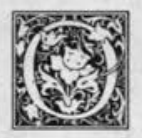

n many college campuses, the careful listener can hear the muted but plaintive cry of the user-instruction librarian: "Why, oh why, didn't they learn these simple things in high school?" Journal articles covering academic library instructional issues frequently decry the entering college student's lack of bibliographic skills and stress the importance of their introduction at the elementary-school level. Certainly concerns about minimal competency are not the province of academic librarians alone.

In recent years, the popular media, the academic press, and government panels have labored over questions of school reform in general and the revision of teacher-training programs in particular. Are these two issues-library skills on the one hand and curricular needs of pupils and future teachers on the other-related in any meaningful way? This article explores that link through a survey of faculty at teacher-training institutions in Ohio. The study was designed to investigate the role of library skills training in teacher preparatory programs, and the results, detailed below, suggest potential areas for improvement in students' informationfinding and critical-thinking skills.

Recent reports on educational reform by state agencies and federal panels indicate that the development of critical-thinking skills is central to the improvement of educational outcomes at all levels. An Ohio report states

Higher order skills such as identifying, analyzing, and solving problems; anticipating and planning outcomes; evaluating consequences of decisions; determining interrelationships; and locating needed information are increasingly being identified as skills that will be needed by students if they are going to be prepared to adapt to changes in the future. ${ }^{1}$

The report further recommends that teaching these skills become an integral part of the school curriculum. And yet this report, and others like it, fail to recognize the direct connection between the library research process and acquisition of those "higher order skills."'

Nancyanne O'Hanlon is Reference Librarian in the Undergraduate Library at Ohio State University, Columbus, Ohio 43210. 
Solving research problems successfully, or "information literacy," involves identifying and analyzing the research question, planning a library search strategy, evaluating information sources found, and determining relationships among different types of information. In short, the process is much like putting together a complex puzzle. These library skills are, in the words of one commentator,

not only important for the development of higher level intellectual skills and knowledge, but also intimately relate to many of the curricular content areas, for example, set theory in mathematics and classification concepts in science. $^{3}$

The belief that "teachers must be information literate if kids are to be information literate ${ }^{\prime \prime 4}$ motivated the study described in this report. Neither school librarians nor teachers can hope to teach library skills in a vacuum; they must be partners in this venture, relating library assignments to the instructional content of the curriculum. For a real partnership to succeed, teachers themselves must be well versed in research techniques and must view the teaching of bibliographic skills as important. In other words, the development of research skills should be an integral part of the teacher-training program.

A logical beginning for an exploration of the information literacy issue is an examination of the attitudes of college faculty at teacher-training institutions. Teachereducation faculty are important participants in the ongoing examination and reform of teacher-training curricula. Awareness of their views on the role of library training in the curriculum is essential to understanding the interrelatedness of library skills instruction and the development of higher-level thinking skills.

\section{SCOPE OF STUDY}

The present study focuses on faculty in elementary-education teacher-training programs in Ohio for several reasons. The state of Ohio hosts a great variety of public and private institutions that can be viewed as representative of teacher-education programs nationally. The curriculum for elementary-education majors includes primarily education courses, where students have contact with education department faculty; in contrast, secondary education students are more likely to encounter library skills in their subjectrelated coursework. In addition, since library skills instruction in the schools begins at the elementary-school level, those teachers and the teacher-training faculty play an important role in the successful development of these skills.

\section{METHODOLOGY}

The following questions form the basis of the study:

1. How do faculty perceive library instruction and its proper role in the teacher-training curriculum?

2. Who should be primarily responsible for library instruction in the teachertraining curriculum?

3. What library skills are needed by graduates of teacher-training programs?

4. What library skills are needed by elementary-school pupils? Who should be responsible for library instruction in the elementary schools?

Additional data were gathered on the availability of library instruction programs, the types of research projects normally assigned to undergraduate students, and faculty assessment of the adequacy of their students' library research skills.

Responses to each question were cross tabulated by a number of variables related to faculty and institutional characteristics to reveal significant differences in attitude. The faculty variables included academic rank, years of college-teaching experience, years of elementary school-teaching experience, and approximate number of elementary-education students taught per year (all selfreported). Institutional characteristics examined were type of sponsorship (private or state-supported institution), size (number of full-time students during the 1983-84 academic year), type of education programs available (undergraduate only and/or graduate), and approximate number of students graduating from the teacher-training program during the 1983-84 academic year (reported by fac- 
ulty returning survey forms). In the following discussion, relevant differences in attitude by variable are described.

In an attempt to elicit responses from as many different kinds of teacher-training programs in Ohio as possible, the chair of the education department at each school was contacted by mail and asked to verify a list of current, full-time permanent faculty active in teaching elementaryeducation courses. Of the 45 colleges and universities contacted initially, 43 had at least one faculty member who fit the criteria.

During January 1985, survey forms were mailed to each of the 328 faculty identified. At least one faculty member at 38 of the 43 schools completed the questionnaire, making the institutional response rate $84 \%$. A profile of the colleges and universities represented in this study and of the individual faculty responding is presented in table 1.

The survey form was designed to elicit demographic information from respondents. All faculty receiving a form were asked to complete at least the first three questions so that information on the characteristics of nonrespondents could be assessed for differences from the group completing the survey. The initial mailing of 328 surveys was followed by a second one to a random sample of those not responding to the first request. In the first round, 196 of 328 forms were returned, and 151 of these were completed fully. In the second mailing of 75 questionnaires, 30 were returned, 24 of which were fully answered. Results of these two mailings were analyzed separately, but no significant differences between the two groups were noted.

Those who returned survey forms as requested, but chose not to participate, were asked to indicate reasons for their choice. Of the 51 individuals in this category, $76 \%$ did not complete the questionnaire because they did not fit the criteria stated in the cover letter. The remaining $24 \%$ chose not to participate for other reasons. Analysis of demographic characteristics of nonrespondents, as self-reported, reveal a group with significantly fewer years of elementary school-and college-teaching experience than the respondents.

A total of 175 forms out of 328 sent were fully completed, for an individual response rate of $53.4 \%$. However, the adjusted response rate (the response rate recalculated to account for the 39 individuals who did not meet the initial criteria) was $60.6 \%$. Five of the 175 forms completed

TABLE 1

PROFILE OF RESPONDENTS

\begin{tabular}{|c|c|c|c|}
\hline $\begin{array}{l}\text { Institutional Characteristics } \\
\text { Sponsorship }\end{array}$ & {$[n=38]$} & $\begin{array}{l}\text { Faculty Characteristics } \\
\text { Rank } \\
\end{array}$ & {$[n=170]^{*}$} \\
\hline $\begin{array}{l}\text { Private schools } \\
\text { State-supported schools }\end{array}$ & $\begin{array}{l}54.1 \% \\
45.9 \%\end{array}$ & $\begin{array}{l}\text { Assistant professor } \\
\text { Associate professor } \\
\text { Full professor }\end{array}$ & $\begin{array}{l}25.3 \% \\
37.95 \% \\
36.75 \%\end{array}$ \\
\hline Enrollment & & $\begin{array}{l}\text { Years of college } \\
\text { teaching experience }\end{array}$ & \\
\hline $\begin{array}{l}\text { Under } 1,000 \text { students } \\
1,000-10,000 \text { students } \\
\text { Over } 10,000 \text { students }\end{array}$ & $\begin{array}{l}17.65 \% \\
37.65 \% \\
44.7 \%\end{array}$ & $\begin{array}{l}10 \text { or fewer } \\
11-17 \\
18 \text { or more }\end{array}$ & $\begin{array}{l}29.4 \% \\
42.4 \% \\
28.2 \%\end{array}$ \\
\hline Program type: & & $\begin{array}{l}\text { Years of elementary } \\
\text { teaching experience }\end{array}$ & \\
\hline $\begin{array}{l}\text { Undergraduate only } \\
\text { Undergraduate/graduate }\end{array}$ & $\begin{array}{l}35.3 \% \\
64.7 \%\end{array}$ & $\begin{array}{l}5 \text { or fewer } \\
6-10 \\
11 \text { or more }\end{array}$ & $\begin{array}{l}38.2 \% \\
30.6 \% \\
31.1 \%\end{array}$ \\
\hline $\begin{array}{l}\text { Number of elementary-education } \\
\text { students graduating } 1983-84^{*}\end{array}$ & & $\begin{array}{l}\text { Number of elementary- } \\
\text { education students taught per year }\end{array}$ & \\
\hline $\begin{array}{l}30 \text { or fewer } \\
31-100 \\
101 \text { or more }\end{array}$ & $\begin{array}{l}44.7 \% \\
30.6 \% \\
24.7 \%\end{array}$ & $\begin{array}{l}50 \text { or fewer } \\
51-120 \\
121 \text { or more }\end{array}$ & $\begin{array}{l}34.7 \% \\
39.4 \% \\
25.8 \%\end{array}$ \\
\hline
\end{tabular}

\footnotetext{
-Faculty characteristics and number of elementary-education students graduating are self-reported.
} 
could not be analyzed because of errors. The survey results were presented in frequency tables and chi-square analyses of cross-tabulations using the SAS statistical analysis program.

\section{RESULTS \\ I. The Role of Library Instruction}

A number of questions in the survey addressed aspects of the usefulness of library instruction and its proper role in the teacher-training curriculum. Four questions concerning the need for elementaryeducation students to learn library research skills and the possible effects of such instruction were presented in Likert scale format. Table 2 shows the frequency distribution of responses to these questions.

Respondents clearly agreed that instruction in library skills should be a part of the teacher-training program and that such instruction would enhance the future teacher's ability to foster elementaryschool pupils' research skill development. No significant differences in response to questions 4,12 , and 24 were noted for any of the variables tested.

Respondents were divided nearly evenly, however, in their attitudes toward the importance of utilizing instructorpresented information as opposed to relying on the ability of the student to generate information independently through research (question 5). When responses to this question were analyzed by selected variables relating to faculty characteristics and institutional size, significant variations became apparent. Table 3 presents these results.

Almost one-fifth of all respondents were undecided on the options presented in question 5. Not surprisingly, those with the fewest years of college- or elementary school-teaching experience and those ranking below full professor were less likely than others either to agree or to disagree with the statement presented in this question. When analysis controlled for years of elementary school-teaching experience was summarized, almost half of those with substantial elementary-school classroom field experience (11 or more years) strongly supported the view that teacher trainees should possess independent research abilities. Responses from those teaching at Ohio's largest institutions, which are generally statesupported, tended to agree with the notion that the ability to digest and use information presented by the instructor is more important than the ability to locate information. In contrast, those teaching in smaller, generally private institutions recognized research ability as more important.

What should be the ideal first priority or goal of teacher-training programs? This is-

\section{TABLE 2}

ROLE OF LIBRARY RESEARCH SKILLS INSTRUCTION IN THE CURRICULUM

\begin{tabular}{|c|c|c|c|c|}
\hline \multicolumn{5}{|c|}{ Respondents asked to indicate degree of agreement with statements below. [ $\mathrm{n}=170$ ] } \\
\hline & $\begin{array}{l}\text { Agreel } \\
\text { Strongly } \\
\text { Agree }\end{array}$ & Undecided & $\begin{array}{l}\text { Disagree/ } \\
\text { Strongly } \\
\text { Disagree }\end{array}$ & $\begin{array}{c}\text { No } \\
\text { response }\end{array}$ \\
\hline $\begin{array}{l}\text { Q.4 Undergraduate students in elementary-education } \\
\text { programs should learn to do research in their field } \\
\text { using library resources. }\end{array}$ & $97.1 \%$ & $1.8 \%$ & $1.1 \%$ & $0.0 \%$ \\
\hline $\begin{array}{l}\text { Q.5 Utilizing information presented in classroom lec- } \\
\text { tures, readings, and discussions in projects is more } \\
\text { important than the ability to do library research. }\end{array}$ & $40.0 \%$ & $18.8 \%$ & $38.3 \%$ & $2.9 \%$ \\
\hline $\begin{array}{l}\text { Q.12 The elementary-school teacher-training curricu- } \\
\text { lum should include formal instruction in research } \\
\text { skills. }\end{array}$ & $75.9 \%$ & $15.9 \%$ & $7.7 \%$ & $0.5 \%$ \\
\hline $\begin{array}{l}\text { Q.24 Elementary schoolteachers will be better pre- } \\
\text { pared to help students learn library research skifls if } \\
\text { they have received formal instruction themselves } \\
\text { during the teacher-training program. }\end{array}$ & $85.9 \%$ & $8.8 \%$ & $4.1 \%$ & $1.2 \%$ \\
\hline
\end{tabular}




\section{TABLE 3}

\section{IMPORTANCE OF LIBRARY RESEARCH SKILLS BY SELECTED FACULTY AND INSTITUTIONAL CHARACTERISTICS}

Respondents asked to indicate degree of agreement with the statement: "Utilizing information presented in classroom lectures, readings, and discussions in projects is more important than the ability to perform library research." [Row percentages are listed]

\begin{tabular}{|c|c|c|c|c|c|c|}
\hline & $\begin{array}{c}\text { Strongly } \\
\text { Agreel } \\
\text { Agree }\end{array}$ & Undecided & $\begin{array}{l}\text { Strongly } \\
\text { Disagree/ } \\
\text { Disagree }\end{array}$ & $\begin{array}{l}\text { No } \\
\text { Response }\end{array}$ & Total & $\begin{array}{c}\text { Combined } \\
\text { in Each } \\
\text { Category }\end{array}$ \\
\hline $\begin{array}{l}\text { Academic Rank } \\
{[n=165]}\end{array}$ & & & & & & \\
\hline Asst. professor & 33.3 & 23.8 & 40.5 & 2.4 & 100.0 & 25.3 \\
\hline Assoc. professor & 41.3 & 23.8 & 30.2 & 4.7 & 100.0 & 37.9 \\
\hline Full professor & 41.0 & 11.5 & 45.9 & 1.6 & 100.0 & 36.8 \\
\hline Combined $^{\star}$ & 39.2 & 19.3 & 38.5 & 3.0 & 100.0 & 100.0 \\
\hline $\begin{array}{l}\text { Years of College } \\
\text { Teaching Experi- } \\
\text { ence }[n=170]\end{array}$ & & & & & & \\
\hline 10 or fewer & 34.0 & 24.0 & 40.0 & 2.0 & 100.0 & 29.4 \\
\hline $11-17$ & 43.1 & 15.3 & 38.9 & 2.7 & 100.0 & 42.4 \\
\hline 18 or more & 41.7 & 18.7 & 35.4 & 4.2 & 100.0 & 28.2 \\
\hline Combined & 40.0 & 18.8 & 38.3 & 2.9 & 100.0 & 100.0 \\
\hline
\end{tabular}

Years of Elementary-School Teaching Experiencet [ $\mathrm{n}=170$ ]

5 or fewer

6-10

11 or more

Combined

41.7

18.7

38.3

$2.9 \quad 100.0$

29.4

42.4

100.0

Institutional Sizet

[ $\mathrm{n}=170$ ]

Fewer than 1,000

$1,000-10,000$ students

More than 10,000

Combined

$\begin{array}{lll}38.5 & 26.1 & 35 . \\ 50.0 & 15.4 & 30 . \\ 32.1 & 13.2 & 49 . \\ 40.0 & 18.8 & 38 .\end{array}$

35.4

30.8

49.1

$\begin{array}{ll}0.0 & 100.0\end{array}$

38.2

38.3

$3.8 \quad 100.0$

$5.6 \quad 100.0$

30.6

$\begin{array}{llr}3.6 & 30.6\end{array}$

*Percentages differ from combined figures for other variables since fewer individuals answering this question also indicated their academic rank.

tDifferences by years of elementary-school teaching experience and by institutional size are statistically significant.

sue was addressed by another question, which asked respondents to rank several options. Almost one-fifth, or $18.1 \%$ of all respondents, indicated that programs should aim first to convey specific facts, concepts, and methods to students. Twothirds, or $66.3 \%$ of those responding, indicated that the ideal first priority of teachertraining programs should be to teach students lifelong or independent-learning skills. The remaining $15.6 \%$ chose the response "neither of the above." No differences in response based on faculty or institutional characteristics were noted.

Respondents were also asked to rank a list of statements on ways in which library research ability could benefit future teachers. Two-thirds, or $66.2 \%$ of respondents, ranked as most important that teachers with these skills will be better able to solve job-related problems and devise effective programs. One-fourth, or $25.4 \%$, chose as most significant the statement that teachers will be better prepared to teach research skills to their students. A small number, $7.7 \%$, saw research ability as an aid to further graduate study in their field. Only 1 individual indicated that no significant benefits result from improved library skills. While respondents to question 24 (see table 2) clearly agreed that formal instruction in library skills would enhance teachers' abilities to foster these same skills in their students, the majority of respondents saw this benefit as less significant than enhancement of the teacher's 
ability to solve job-related problems.

\section{Responsibility for Development of Library Skills}

Respondents clearly agreed that library skills instruction benefits teacher trainees and should be provided in the elementary-education program. The question of how education students should develop these skills was the focus of several survey items.

Faculty were asked, in one question, to indicate whether library skills instruction is a part of the elementary-school teachertraining curriculum at their institutions. Almost $9 \%$ indicated that they did not know whether this type of instruction was offered. Faculty at the largest, statesupported schools most frequently responded in this way $(17.1 \%)$. While $25.9 \%$ of those answering indicated that their institutions had a library research skills instruction program for all elementaryeducation students, $33.3 \%$ of those from the smallest, privately supported schools indicated presence of an instruction program for all education students. Over half of all respondents, $54.7 \%$, indicated that library skills instruction was up to the individual instructors at their institutions.

Faculty were also asked for their opinions on who should be responsible for helping education students acquire library skills. A small number responded that students should acquire these skills on their own $(7.1 \%)$ or should have such skills on entering college $(8.5 \%)$. Almost half of all respondents, $49.6 \%$, indicated that librarians should be primarily responsible for research skill development, while $34.8 \%$ of respondents indicated that the classroom instructor should assume this responsibility. When results were examined for vari- ation by faculty or institutional characteristics, assistant professors and those teaching larger numbers of students were found to favor librarian responsibility for instruction more frequently than the average. Those professors with substantial college-teaching experience (18 or more years) viewed research skills instruction as primarily the instructor's responsibility.

Finally, faculty were asked to indicate preferences for type of library skills instruction. Of those responding to this question, only a small number (3.4\%) indicated that formal instruction was not needed. The remaining response was divided among three options: $30.9 \%$ indicated that instruction should be provided within each individual course, by the instructor; $29.5 \%$ favored classroom presentations, done by librarians; and $25.5 \%$ preferred a separate skills course, taught by a librarian. Only $10.7 \%$ of respondents indicated preference for a separate course taught by an instructor. Thus, the majority favored some type of librarianpresented instruction. No significant variations in response by faculty or institutional characteristics were apparent.

\section{Research Skills of Education Students}

Responses to questions concerning types of research projects assigned, assessment of students' research abilities, and opinions about types of research skills needed by teacher trainees are summarized in this section.

Table 4 describes the types of research projects frequently assigned by faculty. Only those who assign projects requiring library use were asked to respond to this item. One-third, or $33.6 \%$ of all survey re-

TABLE 4

TYPES OF UNDERGRADUATE RESEARCH PROJECTS FREQUENTLY ASSIGNED

\begin{tabular}{lcc}
\hline \hline Project & $\begin{array}{c}\text { Lower Division } \\
{[\mathrm{n}-90]}\end{array}$ & $\begin{array}{c}\text { Upper Division } \\
\text { [n }-113]\end{array}$ \\
\hline Short term paper (to ten pages) & $64.5 \%$ & $51.5 \%$ \\
Research paper (more than ten pages) & $12.2 \%$ & $40.9 \%$ \\
Literature review & $47.1 \%$ & $52.9 \%$ \\
Annotated bibliography & $29.8 \%$ & $40.9 \%$ \\
Book or journal article review & $70.0 \%$ & $74.3 \%$ \\
Report using statistical data & $15.8 \%$ & $24.7 \%$ \\
\hline
\end{tabular}


spondents, did not answer this question. It appears that a large number of elementary-education faculty surveyed either do not require independent research projects or do so very infrequently. Those who do assign research projects favor assignment of book or journal article reviews, short term papers, and literature reviews. Much less frequently assigned are analytical or interpretive projects, e.g., annotated bibliographies, lengthy research papers, and statistical reports.

Respondents to the question above were asked several other questions relating to their students' library skills. Faculty who assign research projects were asked whether they assume that their students know how to use library resources. Over half $(52.3 \%)$ indicated that they did not assume this prior knowledge among lowerdivision students, while $45.9 \%$ indicated that they did. For upper-division students, most faculty $(75.4 \%)$ assumed that students can use library resources effectively, while $23.9 \%$ did not make this assumption. Respondents apparently believe that entering students have low knowledge of techniques of library use, but that at some point in their training, they acquire the necessary skills.

Faculty were also asked to indicate whether, based on evaluation of their research assignments, they would say that students in their classes have adequate library skills. For lower-division students, $64.5 \%$ of those responding answered no to this question and $28.2 \%$ answered yes. For upper-division students, the faculty satisfaction level increased, with $49.3 \%$ of respondents reporting adequate student abilities and $44.2 \%$ indicating inadequate skills. Apparently the assumption by almost half of the respondents that their lower-division students can handle library research projects is not borne out by examination of the students' research projects. Similarly, for upper-level students, expectation exceeds the reality of results, though more upper-division students apparently conduct satisfactory research.

Finally, respondents' attitudes about the specific types of research skills needed by teacher trainees are reported in table 5 . The "research skills" enumerated here reflect a broad definition of this concept. The individual skills listed in table 5 include those most commonly associated with library instructional efforts (skills $2,3,5,6$ ) as well as several "critical-thinking" skills (skills 1,4), which may be seen as a necessary part of the research process but are often not addressed directly in library skills instruction. In the author's view, the information-finding process cannot reach a successful conclusion and will not result in a satisfactory research product unless the information seeker can clearly conceptualize the research question and see patterns or relationships among types of information found.

As table 5 demonstrates, respondents recognized the importance of the ability to conceptualize the research process by ranking it first in a forced ranking of skills. Yet in a later question, which asked faculty to select from all of the listed skills

TABLE 5

TYPES OF RESEARCH SKILLS

\begin{tabular}{lccc}
\hline \hline $\begin{array}{l}\text { Ranked Skills } \\
\text { [n=170] }\end{array}$ & $\begin{array}{c}\% \text { Ranking } \\
\text { Item no.1 }\end{array}$ & $\begin{array}{c}\text { Essential } \\
\text { for Elem. } \\
\text { Schoolteachers }\end{array}$ & $\begin{array}{c}\text { Should Be } \\
\text { Formally } \\
\text { Taught }\end{array}$ \\
\hline $\begin{array}{l}\text { 1. Ability to conceptualize research problems clearly and } \\
\text { determine questions to be answered. }\end{array}$ & $23.5 \%$ & $58.8 \%$ & $51.8 \%$ \\
$\begin{array}{l}\text { 2. Ability to use reference sources (encyclopedias, in- } \\
\text { dexes, etc.). }\end{array}$ & $18.8 \%$ & $80.6 \%$ & $66.5 \%$ \\
$\begin{array}{l}\text { 3. Ability to devise and carry out an organized plan } \\
\text { (search strategy) to find relevant information on a topic. }\end{array}$ & $15.3 \%$ & $72.9 \%$ & $65.9 \%$ \\
$\begin{array}{l}\text { 4. Ability to synthesize information gathered from many } \\
\text { sources. }\end{array}$ & $12.9 \%$ & $78.2 \%$ & $63.5 \%$ \\
$\begin{array}{l}\text { 5. Familiarity with important journals in the field. } \\
\text { 6. Ability to evaluate quality or authority. }\end{array}$ & $12.9 \%$ & $74.7 \%$ & $67.7 \%$ \\
Nonrespondents* & $8.3 \%$ & $69.4 \%$ & $58.8 \%$ \\
\hline
\end{tabular}

\footnotetext{
"Nonrespondents include some individuals who assigned the same rank to several items.
} 
those that are essential for future teachers to possess, this skill was the one least frequently chosen. Respondents also chose the conceptualization process least often when ranking the skills that should be formally taught in the teacher-training program.

There are several possible explanations for these apparently contradictory attitudes. Some respondents might view the ability to conceptualize well as important for those conducting scholarly research but less critical for elementary schoolteachers, who are not essentially "researchers" in the traditional academic context but rather "practitioners" for whom sophisticated research skills are less relevant than other attributes. The results indicated in table 5 might also reflect a rather different view on the interrelatedness of the skills listed than that presented by this writer. The following discussion of research skills instruction in the elementary-school setting provides additional data related to the issue of analytical or conceptual research skills instruction.

\section{Research Skills for \\ Elementary-School Students}

The survey also included some questions asking respondents to indicate attitudes about the types of research skills needed by elementary-school pupils, the role of the classroom teacher in the research skills instruction process, and the ability of current teacher trainees to provide instruction. Table 6 shows the response to two questions that asked faculty to indicate, first, the research skills that, in their opinion, are most frequently taught to elementary-school pupils by teachers or by school librarians, and second, the skills that should ideally be taught to the pupils.

There was little variation in response to these questions by faculty or institutional variables. Respondents indicated that conceptual/analytical skills (item D) and search strategy skills (item E) are, in their view, least frequently taught to elementary-school pupils. These same skills were clearly considered by respondents to be an important part of the library skills instruction process, although the ability to conceptualize well was indicated somewhat less frequently than the others listed.

Several other questions were designed to assess faculty attitudes toward the issue of responsibility for library skills instruction in the elementary-school setting. Faculty were asked who should be primarily responsible for teaching library skills to elementary-school pupils. One-fifth of the respondents indicated that the classroom teacher should have primary responsibility for this instruction, and almost onefifth $(18.8 \%)$ chose the school librarian/media specialist. Approximately three-fifths, or $61.2 \%$, favored sharing the responsibility between teacher and librarian. More than $80 \%$ of respondents indicated that the classroom teacher should be involved in some way in the instruction process.

If classroom teachers should be involved in fostering library skills development in pupils, how well prepared are they for this task? Respondents were asked if they agreed with the statement that after graduating from an Ohio teacher-training program, certified elementary schoolteachers are adequately prepared to teach their students library re-

TABLE 6

RESEARCH SKILLS FOR ELEMENTARY-SCHOOL PUPILS

[Percentages indicate the positive responses to each item]

[Percentages indicate the positive responses to each item]

Research Skills

A. How to use the card catalog

B. How to use encyclopedias and indexes

C. How to find books in the library

D. How to analyze information needs, frame questions to be answered.

E. How to search systematically different kinds of sources to answer questions.
Taught to

Ideally Taught to Elementary-school Elementary-school Pupils [ $=165$ ] Pupils [n $=168$ ]

$90.3 \% \quad 99.4 \%$

$88.4 \% \quad 99.4 \%$

$92.1 \% \quad 99.4 \%$

$19.1 \% \quad 95.0 \%$

$24.2 \%$

$98.2 \%$ 
search skills. Nearly one-third, or $29.6 \%$ of respondents, were undecided. Almost half, or $48.2 \%$, disagreed or strongly disagreed with this statement. The remaining $22.2 \%$ of respondents indicated agreement or strong agreement.

\section{DISCUSSION}

The survey results described here provide some early insights into attitudes of teacher-training faculty regarding library skills development. These results also serve as signposts, pointing the way to issues deserving further study. While development of future teachers' research skills is clearly seen as a worthwhile enterprise, some ambivalence over the role of that development is apparent. Respondents strongly indicated that teaching of independent-learning skills should be the first priority of the teacher-training curriculum, but split on the question of whether the ability to utilize information presented by instructors is more important than the ability to find information independently through library work. Those faculty with the most elementary-school teaching experience strongly favored development of education students' research abilities. While many librarians assume that information-finding skills are an important aspect of lifelong learning skills, it appears that some faculty do not recognize this relationship. Further study of the elements of independent-learning skills as viewed by elementary schoolteachers and teacher-education faculty would provide a basis for dialogue between educators and librarians on this important issue.

Respondents indicated that grasp of library research skills enhances both the teacher's ability to solve job-related problems and to teach these skills to pupils effectively. Yet half of all respondents also view current graduates of Ohio teachertraining programs as inadequately prepared to teach these skills to their students. Most favored teacher involvement in the learning process. Problem analysis was viewed as the most important of the specific research skills listed, but was selected least frequently as a skill essential for future elementary schoolteachers, or one that should be formally taught in the teacher-training program. Do the attitudes expressed here reflect a double standard regarding skills needed by practitioners in the elementary-school classroom and those conducting scholarly research? A closer look at the activities of classroom teachers as researchers and as consumers of research is needed to clarify this question.

At the college level, almost half of the respondents favored librarian involvement in teaching research skills to elementaryeducation students. Faculty at larger institutions and those beginning their academic careers indicated the strongest preference for the librarian as teacher of library research skills. At the elementaryschool level, respondents strongly favored teacher involvement in the research skills learning process. Respondents also indicated that analytical or conceptualization skills and search strategy or planning skills should be taught to elementaryschool pupils as a part of the research process. These same skills were described earlier in this report as some of the higher order, critical-thinking skills that educational reform strategists believe are crucial to the improvement of schooling. If the development of analytical and planning skills is essential for elementary-school pupils, and if elementary schoolteachers should be involved in this process, then why do teacher-education faculty view development of these research skills as peripheral to the teacher-education process? These apparently contradictory attitudes merit further study for clarification.

Insuring the development of criticalthinking skills in elementary-school pupils requires the involvement of classroom teachers at each step of the learning process. In order to play such a vital role in fostering analytical skills, the elementary schoolteacher must have acquired these same abilities. The skills involved in performing library research are the criticalthinking skills cited in current educational reports: identifying, analyzing, planning, locating, evaluating, and interrelating information. Teaching this process to future teachers can, ultimately, improve the critical-thinking abilities of elementaryschool students. 
This study demonstrates that teachereducation faculty support teaching of the library research process, but apparently do not view the development of library skills as necessarily related to the development of critical-thinking skills. Further study of faculty and teacher attitudes toward the research process and toward the relationship of library skills to criticalthinking skills would contribute in an im- portant way to effective reform of the teacher-training curriculum. If teachereducation reform incorporates effective research skills training, then students in elementary and secondary schools in turn will develop more effective library skills, and the plaintive cry of the college instruction librarian will no longer echo across the campus.

\section{REFERENCES}

1. Ohio Commission on Educational Excellence, Responsible Reform: Focusing on the Future (Columbus, Ohio: The Commission, 1983), p.5.

2. For one discussion of library research as a problem-solving task that involves the skills identified as higher-order skills, see Cerise Oberman, "Guided Design: Teaching Library Research as ProblemSolving," in Theories of Bibliographic Education, ed. Cerise Oberman and Katina Strauch (New York: Bowker, 1982), p.111-13.

3. James W. Liesener, "Learning at Risk: School Library Media Programs in an Information World," in Libraries and the Learning Society: Papers in Response to A Nation at Risk (Chicago: American Library Assn., 1984), p.79.

4. Ibid., p.89.

5. No published studies relating to this topic were found in a survey of the educational and library literature. There is an unpublished doctoral dissertation on the subject. See Camilla Ann Alire, "A Nationwide Survey of Education Doctoral Students' Attitudes Regarding the Importance of the Library and the Need for Bibliographic Instruction" (Ed.D. diss., Univ. of Northern Colorado, 1984). 